\title{
The investigation of the interaction of armodafinil with membrane lipids by using DPPC model membrane system
}

\section{Armodafinil'in membran lipidleri etkileșiminin DPPC model membran sistemi ile araștırılması}

\author{
Handan KIRKOÇOĞLU1', Sevgi TÜRKER-KAYA ${ }^{1}$
}

\begin{abstract}
Objective: Armodafinil (ARM), the R-enantiomer of the racemic compound of modafinil, is a central nervous system (CNS) stimulant and wakefulness-promoting used in sleep disorders with unknown exact cellular mechanism. Although it was shown that it does not binds to enzymes and receptors that regulate sleep/wake regulation as well as it is very-well distributed in the body, there is no report evaluating its CNS availability to the best of our knowledge. Considering that lipid solubility of a drug directly affects CNS accessibility, the investigation of ARM how to penetrate into and to interact with lipids would be beneficial to contribute to such issue. Related with this, the interaction of ARM with simplified model membrane system named dipalmitoylphosphatidylcholine (DPPC) multilamellar vesicles (MLVs) depending on concentrations was investigated in the present study.

Methods: The effects of ARM as a function of concentration (1-10-20 mol \%) on main transition temperature $(\mathrm{Tm})$, enthalpy $(\Delta \mathrm{H})$, cooperativity unit (CU) and frequency values of $\mathrm{CH} 2$ asymmetric, $\mathrm{C}=\mathrm{O}$ symmetric and PO2- asymmetric stretching of DPPC MLVs were studied by utilizing differential scanning calorimetry (DSC) and fourier transform infrared (FT-IR) spectroscopy.
\end{abstract}

\section{ÖZET}

Amaç: Modafinilin rasemik bileșiğinin R-enantiyomeri olan Armodafinil (ARM) tam olarak bilinmeyen hücresel etki mekanizması ile uyku bozukluklarında kullanılan merkezi sinir sistemi (MSS) uyarıcı ve uyanıklığı arttırıcı bir ajandır. Her ne kadar ARM'nin uyku/uyanıklık düzenini etkileyen enzimlere ve reseptörlere bağlanmadığı ve vücutta çok iyi dağıldığı gösterilse de, bildiğimiz kadarıyla onun MSS'deki etkinliğini değerlendiren bir çalıșma bulunmamaktadır. Bir ilacın lipid çözünürlüğünün onun MSS erișilebilirliğini direkt olarak etkilediği göz önünde bulundurulduğunda ARM'nin lipidlerin içine nasıl nüfuz ettiği ve onlarla ne tarz etkileșmelere girdiğinin araștırılması bu konuya faydalı katkılar sağlayabilir. Bu bağlamda, bu çalıșmada dipalmitoilfosfatidilkolin (DPPC) multilamellar veziküler (MLVs) adlı basitleștirilmiș model membran sistemi ile ARM'in konsantrasyona bağlı etkileșmeleri araștırıldı.

Yöntem: ARM'nin DPPC MLV'lerinin ana geçiş sıcaklığı $(\mathrm{Tm})$, entalpi $(\Delta \mathrm{H})$, kooperatiflik birimi $(\mathrm{CU})$ ve $\mathrm{CH}_{2}$ asimetrik, $\mathrm{C}=\mathrm{O}$ simetrik ve $\mathrm{PO}_{2}$ - asimetrik frekans değerleri üzerine etkileri konsantrasyona bağlı (\% 1-10$20 \mathrm{~mol}$ ) olarak diferansiyel tarama kalorimetresi (DSC) ve fourier dönüşümü infrared (FT-IR) spektroskopisi kullanılarak incelendi.

${ }^{1}$ Kocaeli University, Faculty of Arts and Sciences, Department of Biology, Kocaeli

İletişim / Corresponding Author : Sevgi TÜRKER-KAYA

Kocaeli Üniversitesi, Fen Edebiyat Fakültesi, Biyoloji Bölümü, 41380 Kocaeli - Türkiye

Tel : +905337204580 E-posta / E-mail : sevgitrkr@gmail.com

Geliş Tarihi / Received : 01.09.2017 Kabul Tarihi / Accepted : 19.07 .2018

DOI ID : 10.5505/TurkHijyen.2018.68094

Kırkoçoğlu H, Türker-Kaya S. The investigation of the interaction of armodafinil with membrane lipids by using DPPC model membrane system.

Turk Hij Den Biyol Derg, 2019; 76(1): 41-52 
Results: All data showed that with the addition of ARM at all concentrations into pure DPPC MLVs, decreased lipid order (acyl chain flexibility), but increased lipid dynamics (fluidity), glycerol backbone and hydrogen bonding capacity head groups of lipids in the gel and liquid crystalline phases. Moreover, it also caused to shift $\mathrm{Tm}, \Delta \mathrm{H}$ and $\mathrm{CU}$ to lower values.

Conclusion: The corresponding findings revealed that ARM has high affinity for binding to acyl chains and hydrophilic parts of phosphatidylcholine lipids. This was also supported by the obtained differences in the thermotropic properties of lipids caused by ARM. The high tendency of ARM to interact with lipids may also mean that it may also lead to perturb the packing of membrane lipids. The results provides incorporation profile of ARM into biological membranes depending on concentration, which may further contribute to new drug development against sleep disorders and related diseases.

Key Words: Darmodafinil, FT-IR spectroscopy, DSC, drug-lipid interaction, dipalmitoylphosphatidylcholines

\section{INTRODUCTION}

Sleep disorders are one of the common and serious diseases affecting the quality of life and activities of the individual during the day. Several drugs for the treatment were used and are still being developed (1-2). Armodafinil (ARM) (Figure 1), marketed under brand name Nuvigil, is one of the most commonly used medications for the treatment of these disorders. It is R-enantiomer of racemic compound of modafinil, and is a central nervous system (CNS) stimulant and wakefulness-promoting used in sleep disorders, sleep apnea, narcolepsy, and circadian rhythm disorders (3-4). There are limited reports in the literature related with its action. It was reported to inhibit the reuptake of dopamine to increase its level in some
Bulgular: Elde edilen tüm verilere göre saf DPPC MLV'lerine ARM eklenmesiyle, lipit düzeninde (açil zincir esnekliği) azalmaya karșılık lipid dinamiği (akıșkanlık), gliserol omurgası ve lipid kafa gruplarının hidrojen bağlama kapasitelerinde sıvı ve kristal fazda artma olduğu tespit edildi. Ayrıca, Tm, $\Delta \mathrm{H}$ ve $\mathrm{CU}$ parametrelerinin de daha düșük değerlere kaydığı bulundu.

Sonuç: Tüm bulgular, ARM'nin, fosfatidilkolin lipidlerinin açil zincirlerine ve hidrofilik kısımlarına bağlanmak üzere yüksek afinite gösterdiğini ortaya koydu. Bu durum ARM'nin lipidlerin termotrofik parametrelerinde neden olduğu farklılıklarla da desteklendi. ARM'nin lipidlerle yüksek oranda etkileșime girme eğilimi onun membran lipidlerinin paketlenmesini bozmasına da neden olabileceği anlamına gelebilir. Elde edilen tüm sonuçlar ARM'nin biyolojik membranlar ile ne tarz etkileșmelere girdiği ile ilgili bilgiler sunmakla birlikte uyku düzensizlikleri ve ilgili hastalıklara karșı yeni ilaç geliștirme çalıșmalarına katkı sağlayabilir.

Anahtar Kelimeler: Darmodafinil,FT-IR, DSC, ilaçlipid etkileșmeleri, dipalmitoilfosfatidilkolin

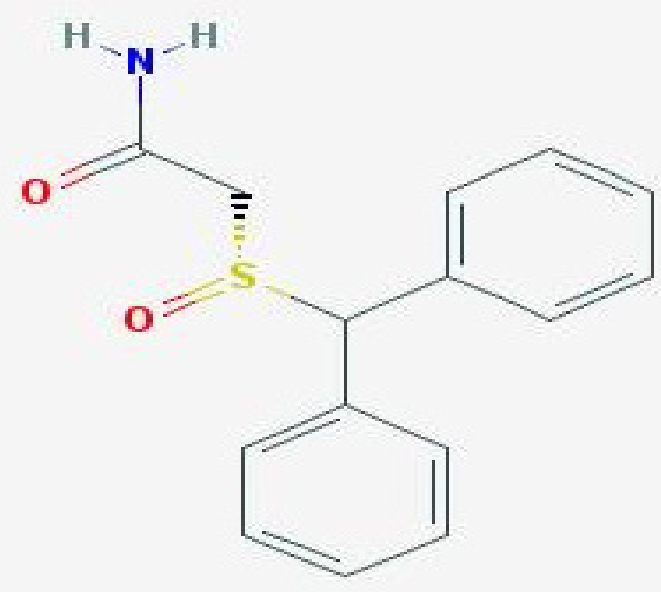

Figure 1. Chemical structure of ARM 
brain regions. Moreover, ARM does not act directly or indirectly as a dopamine receptor agonist.

ARM must cross phospholipid bilayers to reach their site of action and to act in brain. Related with this, molecular interactions of ARM with membrane lipids play an important role in its transport, distribution, accumulation, efficacy and eventually CNS availability (5-6). Thus, the affinity of the drug to lipids can provide useful information for the understanding of its partition profile into membranes, and relatively effectiveness. This may further develop potent drugs for the treatment of sleep disorders as also suggested for different diseases (7-11). According to the literature ARM neither binds to nor inhibits enzymes and receptors that regulate sleep/ wake regulation. Furthermore, unlike drugs that act by binding proteins, it was shown to be very well distributed in the body and not to show high affinity in tissues (12-13). Considering all these ARM may have higher propensity to interact with membrane lipids. This may further facilitate its longer halflife than modafinil (13). However, related with this issue, there is no study available of ARM-membrane interactions in the literature at molecular level to the best of our knowledge. For such research the utilization of artificial membrane systems is a general approach since it is difficult to interpret interactions of drug with certain types of lipids with studies using whole biological membrane fractions containing many different types of lipids $(7-9,14)$. Particularly, dipalmitoylphosphatidylcholine (DPPC) bilayers are known as suitable models to mimic membranes since phosphatidylcholines (PCs) are major lipid components of eukaryotic membrane systems (7-9).

In the current study, we aimed to investigate interaction of ARM at different concentrations with DPPC MLVs in terms of the changes in lipid thermotropic parameters, order and dynamics and hydration state of the polar part of lipids. To achieve this, we used differential scanning calorimetry (DSC) and Fourier transform infrared (FT-IR) spectroscopy both of which are widely performed for these kinds of studies $(7-9,15-21)$.

\section{MATERIAL and METHOD}

\section{Chemicals}

ARM [2-[(R)-(diphenylenylmethyl)sulphynil] acetamid], DPPC and phosphate buffered saline (PBS) tablets were purchased from Sigma (St. Louis, MO, USA). All chemicals were obtained from commercial sources at the highest grade of purity available.

\section{MLVs Preparation}

DPPC MLVs in the absence and presence of ARM (110-20 mol \%) were prepared by following the previous reports (7,9,19-21). Shortly, $5 \mathrm{mg}$ DPPC lipids were dissolved in round bottom glass tubes in chloroform, under nitrogen flow and vacuum overnight the solvent were evaporated. Then, thin films of lipids were obtained and re-suspended in $25 \mu \mathrm{L}$ PBS buffer, $\mathrm{pH}$ 7.4. MLVs were formed by vigorous and low frequency vortexing the mixture for $30 \mathrm{~min}$ at least $150 \mathrm{C}$ above Tm of DPPC lipids. On the other hand, the required amount of drug was initially placed in tube to produce drug containing MLVs. The excess of chloroform was removed by a stream of nitrogen, DPPC in chloroform was added and MLVs was prepared as described above. (The light microscopy photograph of MLVs sample is illustrated in Supplementary Information).

\section{FT-IR Studies and Analysis}

All samples placed between calcium florur windows with $12 \mu \mathrm{m}$ sample thickness were scanned by a Perkin Elmer Spectrum 100 FT-IR spectrometer (Perkin Elmer, Inc., Norwalk, CT, USA) equipped with a deuterated triglycine sulfate detector. The interferograms were averaged for 100 scans at 2 $\mathrm{cm}^{-1}$ resolution. Spectral acquisition were performed at $25-60^{\circ} \mathrm{C}$ and, before each scan the samples were incubated for $5 \mathrm{~min}$. All experiments were three times performed. The sample compartment in the FT-IR spectrometer was continuously purged with dry 
air to prevent water vapor. The spectrum of air was automatically subtracted by Perkin Elmer Spectrum One software.

In order to eliminate overlapping effect of the $\mathrm{OH}$ stretching modes $\left(3400-3200 \mathrm{~cm}^{-1}\right.$ and 1800 $1500 \mathrm{~cm}^{-1}$ ) from water molecules in buffer spectrum at each corresponding temperature was subtracted by using same program.

For spectral analysis, Perkin Elmer Spectrum One software was used. Data analysis was performed on water subtracted sample spectra. The band positions were measured from the center of weight $(0.80 \times$ peak height positions) and bandwidth value were calculated as the width at $0.75 \times$ height of the signal in terms of $\mathrm{cm}^{-1}$.

\section{DSC Studies}

MLVs were similarly prepared by following the procedure in FT-IR sample preparation mentioned above for DSC studies. MLVs suspensions were encapsulated in hermetically sealed standard aluminum DSC pans. Measurements were performed using a Shimadzu DSC-60 Calorimeter (Shimadzu Corporation, Tokyo, Japan). Scans were made at $0.5^{\circ} \mathrm{C} / \mathrm{min}$. Samples were scanned three times to ensure the reproducibility of the endotherms. Data were analyzed using TA 60 software provided by Shimadzu. The temperature at the peak maximum was defined as the main transition temperature (Tm). The enthalpy $(\Delta \mathrm{H})$ and cooperativity unit values were calculated as performed in Turker et al., (2011) (7).

Statistical analysis

The mean of at least three experiments was plotted and calculated together with the standard error of mean in the figures and tables. Statistical significance was assessed using Mann-Whitney $U$ test. Significant differences were statistically considered at the level of $p \leq 0.05$.

\section{RESULTS}

Within the scope of the study, the effects of different concentrations of ARM on hydration state of head groups and glycerol backbones, lipid dynamics (fluidity), lipid acyl chain flexibility (ordering) and phase behavior properties of DPPC MLVs were studied by DSC and FT-IR spectroscopy.

In DSC studies, two transitions were exhibited in $30-50{ }^{\circ} \mathrm{C}$ range for pure DPPC MLVs as illustrated in Figure 2. Two peaks were observed. The first one is the pre-transition peak representing the mobility of choline and polar head groups of lipids. As demonstrated in the figure, addition of ARM caused abolishment of pre-transition peak. On the other hand, the second peak attributed to the main transition of the lipids is relating to the mobility of the alkyl chains $(7,15,16)$. Detail analysis of DSC main transition curve is shown in Table 1 representing the values of $\mathrm{Tm}, \Delta \mathrm{H}$ and $\mathrm{CU}$ values of DPPC MLVs without and with ARM. Upon analysis, Tm value of pure DPPC MLVs was obtained as $41.20{ }^{\circ} \mathrm{C}$, which is accordance with the literature $(7,9,15)$. In addition to visual observation of DSC curves, as represented in Table 1, the presence of ARM was found to alter the main phase transition parameters, particularly, a reduction in $\mathrm{Tm}, \Delta \mathrm{H}$ and $\mathrm{CU}$ values.

For FT-IR spectral interpretation, the effects of ARM on frequency values of the $\mathrm{CH} 2$ asymmetric $\left(\sim 2925 \mathrm{~cm}^{-1}\right), \mathrm{C}=\mathrm{O}\left(\sim 1740 \mathrm{~cm}^{-1}\right)$ and the PO2- $(\sim 1222$ $\mathrm{cm}^{-1}$ ) symmetric stretching modes were evaluated in the range of $25-60{ }^{\circ} \mathrm{C}$. Additionally, the bandwidth values of the $\mathrm{CH} 2$ asymmetric stretching values were calculated. Figure 3 shows representative FT-IR spectra of DPPC MLVs in the absence and presence of ARM at $20 \mathrm{~mol} \%$ in the liquid crystalline phase (50 ${ }^{\circ} \mathrm{C}$ ), in the region of $3050-2800 \mathrm{~cm}^{-1}$. As represented in the figure, the modes in such region was sufficiently separated after water subtraction. For this reason, any additional pre-spectral analysis such as deconvolution 


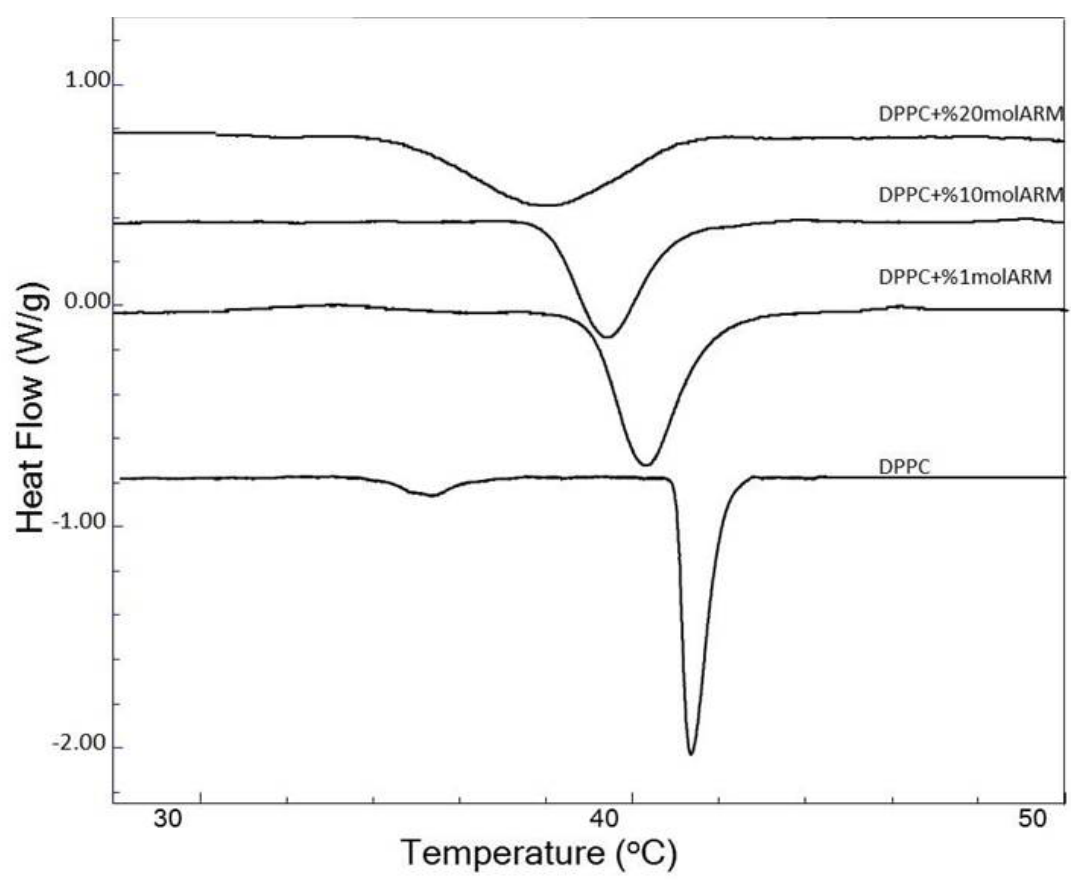

Figure 2. DSC thermograms of DPPC MLVs in the absence and presence of different concentrations of ARM

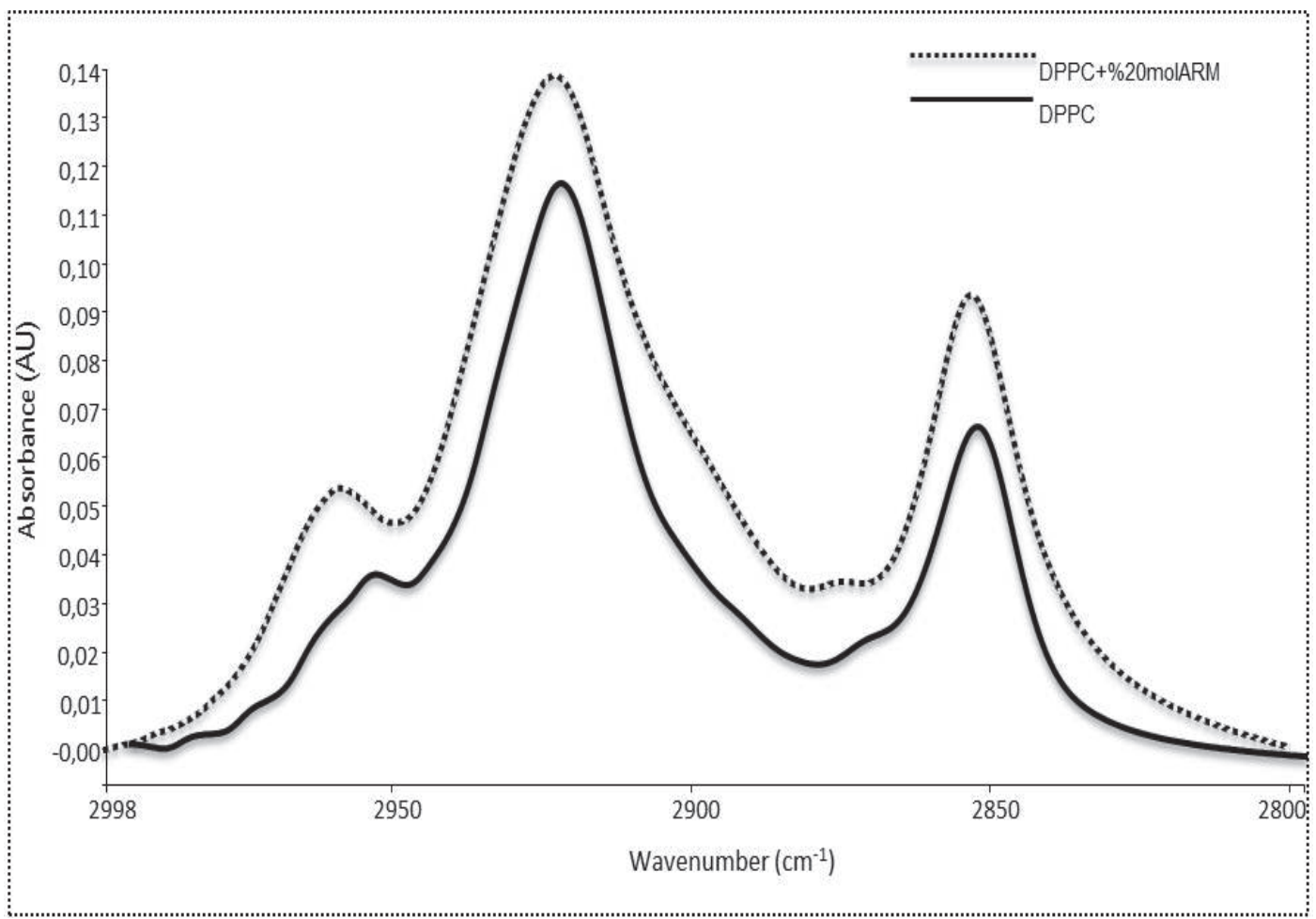

Figure 3. Infrared spectra of DPPC MLVs in the absence and the presence of ARM at $55^{\circ} \mathrm{C}$ in the $3050-2800 \mathrm{~cm}^{-1}$ region. (The spectra were normalized with respect to the $\mathrm{CH} 2$ asymmetric stretching mode at $2925 \mathrm{~cm}^{-1}$ ). 
was not performed. The frequency alterations in the $\mathrm{CH} 2$ asymmetric stretching in addition to pure DPPC MLVs was represented in Figure 4. As observed from the figure, ARM caused shifting of the frequency values of the $\mathrm{CH}_{2}$ asymmetric stretching to higher values in both gel and liquid crystalline phases at all concentrations. The effects of ARM on dynamics (fluidity) of DPPC MLVs were studied by measuring the bandwidth values of the same mode (8-9). Table 1 also demonstrates the changes in the bandwidth values of all samples at two different temperatures corresponding to gel and liquid crystalline phases of DPPC MLVs. According to the table, ARM at all concentrations (1-10-20 mol \%) increased, particularly significant at high concentrations, bandwidth values of the mode.

The temperature dependent frequency variations of $\mathrm{C}=\mathrm{O}$ and $\mathrm{PO}-2$ symmetric stretching in the absence and presence of ARM are shown in Figures 5 and 6 , respectively. As illustrated in the figures, ARM was found to result in a decrease in the frequency both modes, which may mean that a higher hydrogen bonding capacity of glycerol backbone and head groups of DPPC lipids $(7,9,22-23)$.

\section{DISCUSSION}

TARM is expected to interact with membrane lipids and partition into membrane due to having low molecular weight, not binding to protein and not showing affinity in tissues (13). In particular, the partition coefficient values, measured octanol-water system, $\log \mathrm{P}$ at $\mathrm{pH}$ 7.4, which is 1.7 (24) assume its affinity to membrane lipids. But, here, it is worth mentioning that due to lack of ester and amide

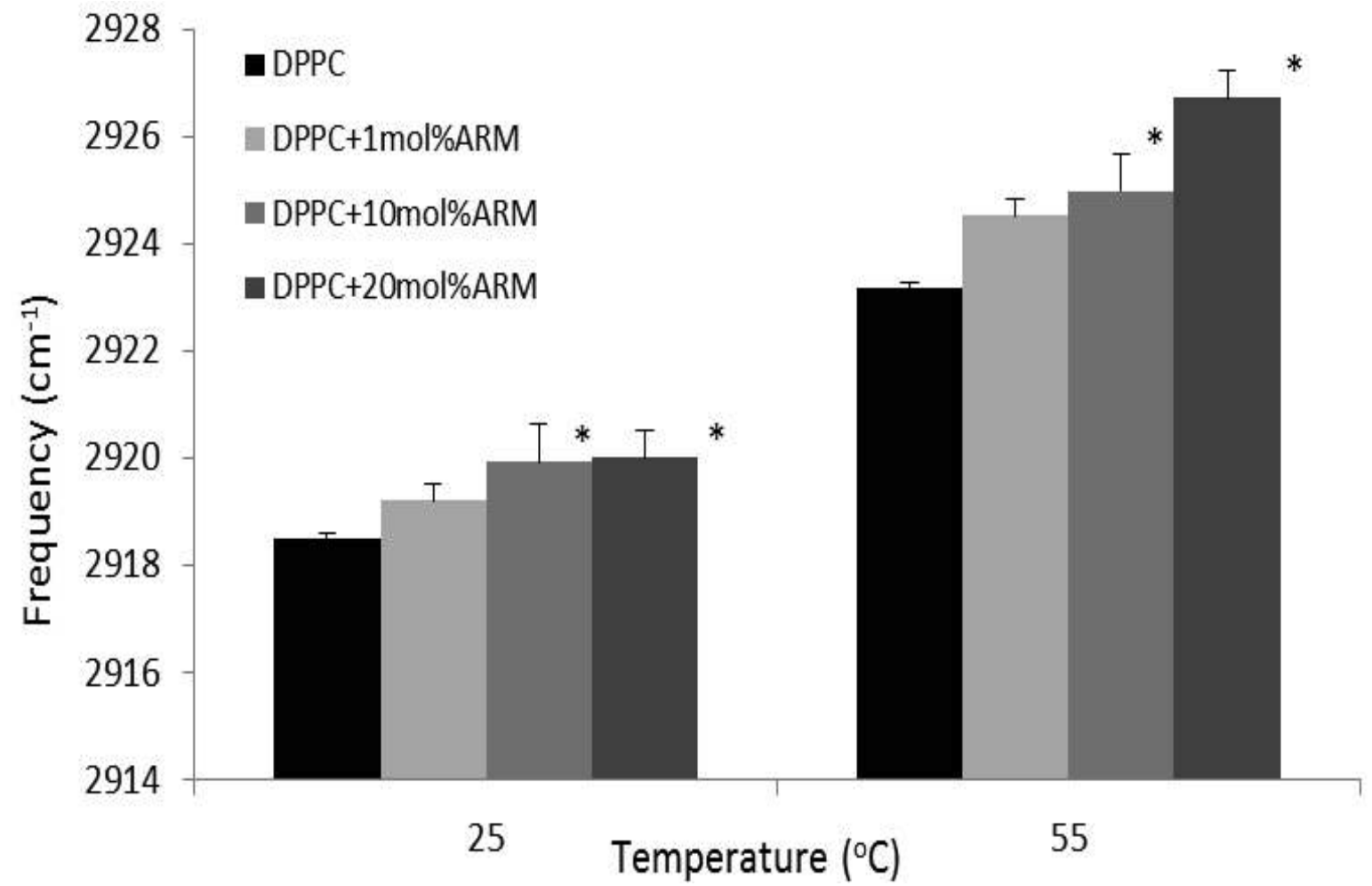

Figure 4. The frequency values of the $\mathrm{CH} 2$ asymmetric stretching modes of DPPC MLVs in the absence and presence of PTZ in varying concentrations at 25 and $55^{\circ} \mathrm{C}$. 


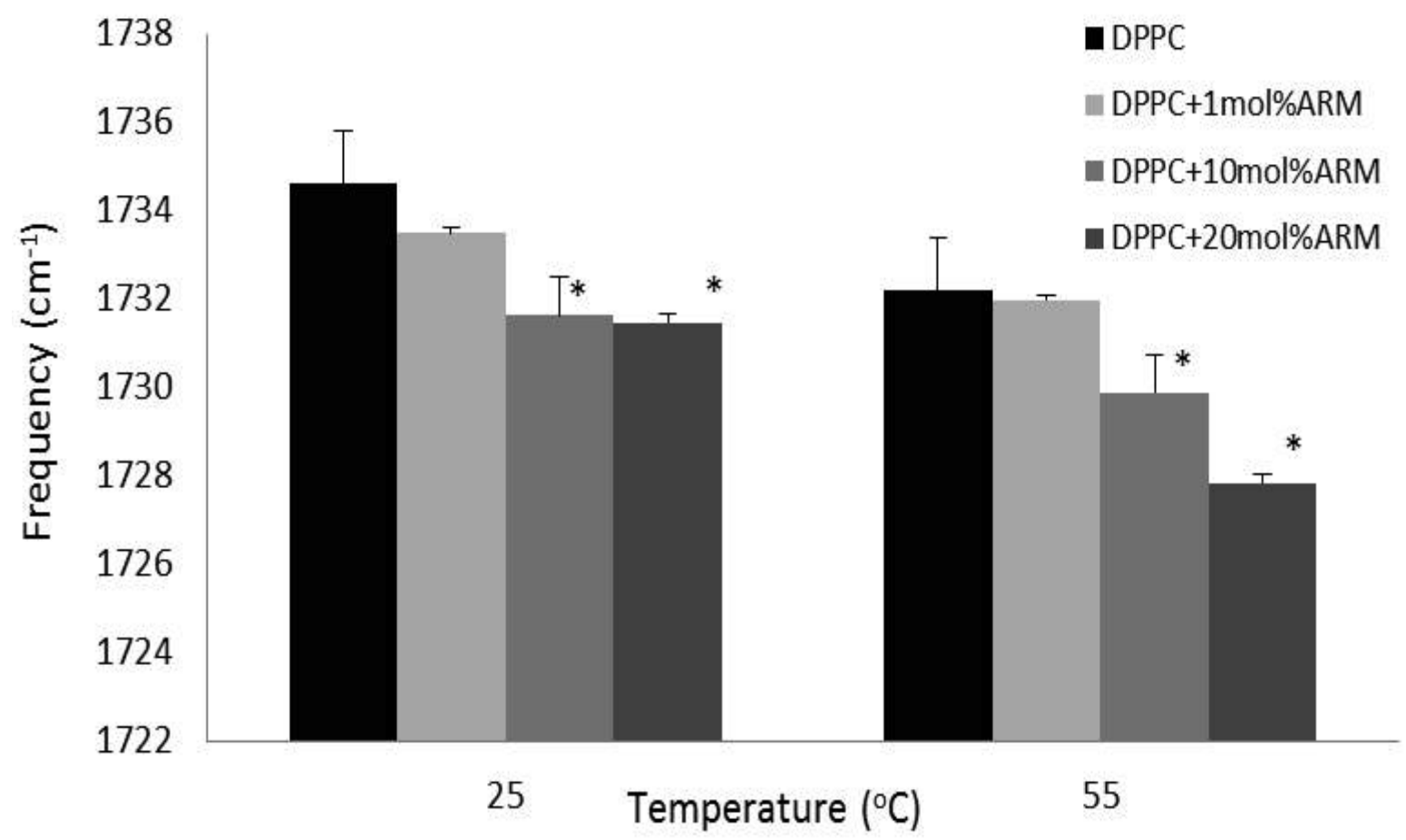

Figure 5. The frequency values of the $\mathrm{C}=0$ stretching modes of DPPC MLVs in the absence and presence of PTZ in varying concentrations at 25 and $55^{\circ} \mathrm{C}$.

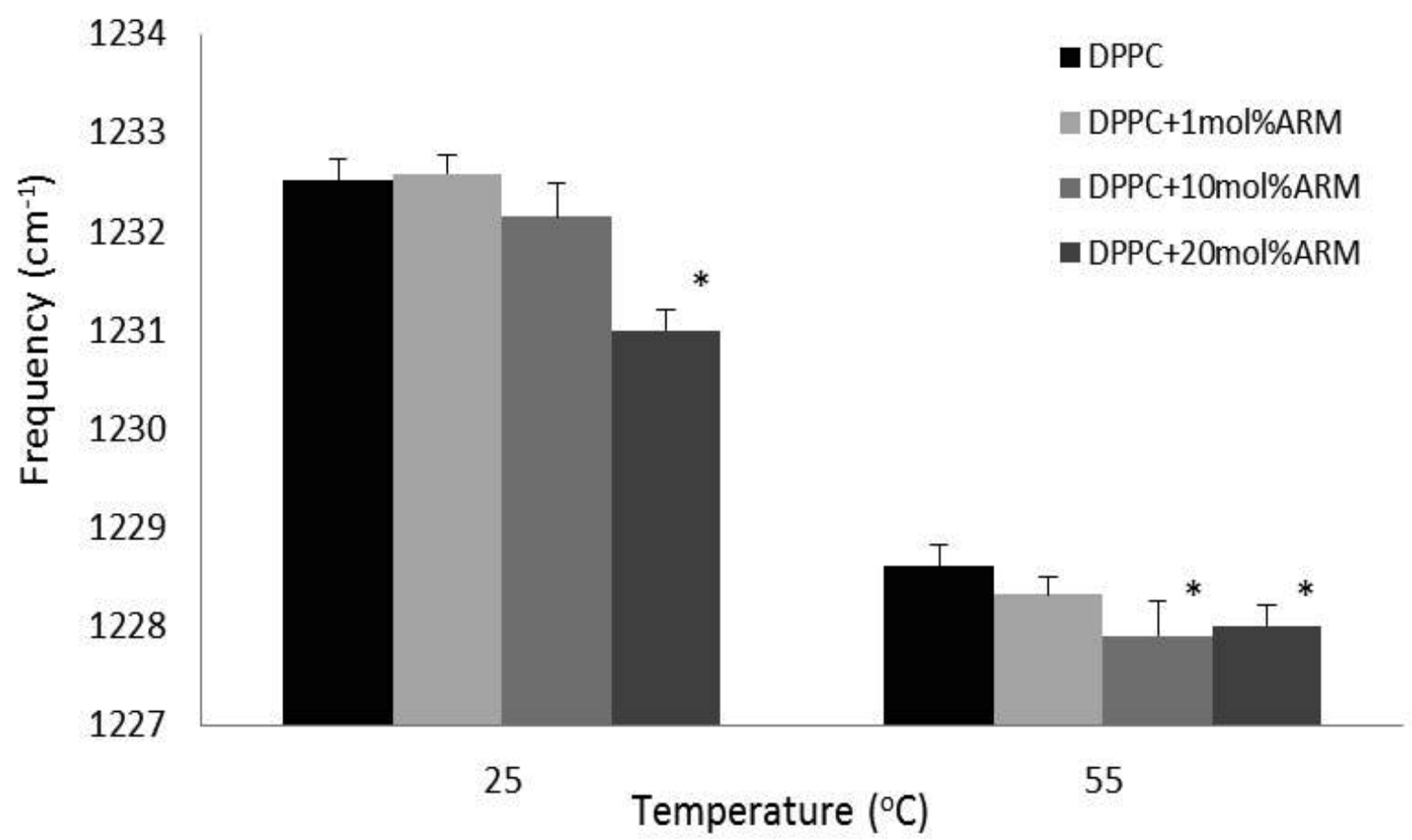

Figure 6. The frequency values of the $\mathrm{PO}_{-2}$ asymmetric stretching modes of DPPC MLVs in the absence and presence of PTZ in varying concentrations at 25 and $55^{\circ} \mathrm{C}$. 
groups naturally present in phospholipids octanolwater system may not represent behavior of the drugs in biological membranes. Therefore, the study of interaction of ARM with membrane lipids obviously provides contribution for clarification of cooperation potency of ARM with membranes. Taking this into consideration, in the current study, the interaction of ARM at different concentrations with DPPC MLVs were examined by DSC and FT-IR spectroscopy. DSC is a tool to study the thermal behavior of lipid bilayers by measuring thermodynamic parameters (i.e. $\Delta \mathrm{H}$ and $\mathrm{Tm}$ ) associated with the phase transitions of lipids. It gives useful information about incorporation degree of drug into lipids. On the other hand, FT-IR spectroscopy provides evidences about the effects of the drugs on lipid dynamics (fluidity), lipid acyl chain flexibility (ordering), hydration state and phase behavior properties of lipids. So, both techniques have been widely used for the investigation of druglipid interactions (15-21, 25-26).

DPPC lipids utilized in the present study represent spontaneous self-assembly into bilayers when dispersed in water, which render biological membranes their basic lamellar structure. Thus, they structurally mimic biological membranes (7$9,22,27)$. However, it is worthy mentioning that model membrane preparation procedures have different critical points that determine membrane features such as type, shape and behavior. Therefore, the parameters like lipid amount, hydration, temperature, osmolarities and cations should be taken specific attention for membrane preparation (28). Among such affects hydration is very important because the specific interactions in which water is involved are very crucial for model-membrane stability (20). Buffer solution provides a highly polar environment that drives the hydrophobic acyl chains to form vesicles that are spontaneously formed in multilamellar arrangement (29). This is energetically most-favorable arrangement. In particular, MLVs like in our case, the product of hydration is a large, MLVs analogous in structure to an onion, with each lipid bilayer separated by a water layer. The spacing between lipid layers is dictated by composition with poly-hydrating layers being closer together than highly charged layers which separate based on electrostatic repulsion. Given significance of water, if excess water and/or fewer lipids are applied, lipid molecules cannot be close enough to construct layer form and the system cannot be settled. This may result in membrane leakage. If less water and/ or higher lipids is applied, lipids aggregate and hydration cannot be fulfilled efficiently (30). In sum, in both cases MLVs are not formed properly. Taking all these into consideration, for MLVs preparation, we followed the previous studies that performed optimized experimental conditions (20-21).

As obtained from DSC results, abolishment of the pre-transition peak with addition of ARM may reveal perturbation or extreme broadening of ripple phase. It is very well known that head group hydration of lipids plays crucial role in pre-transition linked to periodic ripples on the membrane surface (31). Considering this, ARM itself has 1 hydrogen bond donor and 3 acceptor counts (24). Thus, it is expected to interact with hydrophilic part of DPPC lipids. In order to detail whether ARM interacts with glycerol and head groups of lipids, the frequency values $\mathrm{C}=\mathrm{O}$ and $\mathrm{PO}-2$ symmetric stretching bands in the scope of FT-IR study were monitored. The decreased frequency values of both $\mathrm{C}=\mathrm{O}$ and $\mathrm{PO}-2$ symmetric stretching with the addition of ARM (1-10$20 \mathrm{~mol} \%$ ) may imply that the carbonyl groups of the glycerol backbone and head groups of phospholipids are favored hydrogen bonding sites for this compound $(7-9,19,23)$. This may also show that new $\mathrm{H}$ bonds are formed. Such bonding can occur in between the $\mathrm{C}=\mathrm{O}$ and the PO-2 groups of DPPC lipids and either with $\mathrm{N}-\mathrm{H}$ and $\mathrm{O}$ groups of ARM or water molecules rather than lipids each other. However, it is high probable that ARM locates along with carbonyl groups and first C atoms of the acyl chains of PCs, forming bonds with carbonyl esters and phosphate groups (32). This kind of interaction of ARM with these groups of lipids may 
cause ARM to accumulate surface of the bilayer and to remain a shield around membrane lipids. With its impact, the increase in hydrogen bonding capacity in $\mathrm{C}=\mathrm{O}$ and $\mathrm{PO}-2$ groups of DPPC lipids may cause an increment in the head group volume (33). Thus, a protective effect on membrane surface can be created. As reported in the literature, modafinil that is enantiomer of ARM has neuroprotective effects, which may be related to its alerting actions (34). To the best of our knowledge, similar effect has not been shown for ARM, however; tendency of ARM to cover surface of the bilayer structure might be one of such actions same with modafinil's. On the other hand, as one of the side effects of ARM, it leads to thirst and diarrhea (35). This effect may be resulted from the removal of water from the medium. Instead, ARM may compete with water to interact with hydrophilic portion of lipids as also found in the current study.

Such observed changes in hydrophilic parts of the lipids induced by ARM may further cause some alterations in main transition parameters such as broadening of the transition curve, a decrement in $\mathrm{Tm}, \mathrm{CU}$ and $\triangle \mathrm{H}$ as also found in DSC data (Figure 2 and Table 1) (7-9,15-17). These observations can be referred partition of ARM molecule into lipids (7-9,1517,36-37). As also illustrated in Figure 2, broaden main transition of DPPC MLVs can be also related with the lower degree of cooperativity of lipids that shows a decrement in the number of molecules undergoing transition simultaneously $(7,15-17,36)$. On the other hand, decreased Tm value might be indicative of the strength of the interactions of adjacent lipid molecules in the bilayer, primarily by the disruption of polar head group-head group interactions with the presence of ARM. Moreover, a decrement in $\Delta \mathrm{H}$ together with broadening of transition may imply perturbation of normal phase transition of DPPC (21,36-37). It may mean that in such system, the total energy involved in the transition is lowered because the number of lipid molecules involved in the temperature-induced transition is reduced $(7,8,15,21,36-37)$. This may be resulted from preferentially localization ARM in outer hydrophobic cooperative zone of the bilayer, i.e. the region of $\mathrm{C}_{1}-\mathrm{C}_{8}$ atoms of the acyl chains. Such localization can be achieved by disturbing van der Waals interactions between acyl chains, and thereby a loss of bilayer packing $(7,9,36)$.

By analyzing the frequency changes of the $\mathrm{CH}_{2}$ asymmetric stretching modes we brought more clarification for whether ARM can localize within the bilayer or not. And, FT-IR parameters related with such band revealed that ARM at all concentrations decreased trans and/or increased gauche conformers within the system indicating an disordered state (7$9,19,23)$. This data also confirm that in disordered membrane state lowered $\mathrm{Tm}$ and enthalpy values are expected (36). The destabilizing effect of ARM reported in the present study may be accepted as its one of mechanisms in wakefulness promoting. However, it should be taken into consideration that the present study was performed on artificial membrane system. More research on purified brain cell membranes is needed to further elucidate such effects.

As mentioned above, precise action mechanisms of ARM to promote alerting has not been fully elucidated. One of the possibilities may be that ARM can act on these proteins. Since membrane proteins are in highly contact with membrane lipids. Any alteration in their physical properties and hydrogen states may further affect their structure and relatively functions. Obtained corresponding results from the current study ARM induced variations in acyl chains, glycerol and head group regions of DPPC lipids. From this, the interaction of ARM with glycerol backbone and head groups of lipids may potentially change structure; relatively function, of peripheral proteins. Similarly, the localization of ARM within hydrophobic core of bilayer may also suggest that it may alter transmembrane segments of integral proteins (38).

As a conclusion, in the current study, with the aiming to test whether ARM interacts with membrane lipids, the concentration dependent effects of 
the drug on structure and dynamics of DPPC MLVs were investigated. The results indicated that with increasing concentration ARM incorporates into DPPC MLVs, particularly, localizing within acyl chains of lipids and affecting their thermotropic properties. Its binding affinity to hydrophilic parts of lipids was found to highly correlate with lipid-water partition and their solubility degree in water. These results are likely contribute to better understanding of behavior of ARM within real membrane systems, especially mostly containing PCs widely found in brain cell membrane. As a perspective, in order to bring more clarification about molecular action mechanisms of ARM in biological membrane systems with various lipid compositions more studies should be performed on isolated lipids from brain tissues.

\section{REFERENCES}

1. Ballas C, Dinges DF. Stimulant and wake-promoting substances. Encyclop Neurosci, 2009; 1: 419-24.

2. Wang Z, Liu JF. The molecular basis of imsonia: implication for therapeutic approaches. Drug Dev Res, 2016; 77: 427-36.

3. Harsh JR, Hayduk R, Rosenberg R. The efficacy and safety of armodafinil as treatment for adults with excessive sleepiness associated with narcolepsy. Curr Med Res Opin, 2006; 22: 761-74.

4. Czeisler CA, Walsh JK, Wesnes KA. Armodafinil for treatment of excessive sleepiness associated with shift work disorder: a randomized controlled study. Mayo Clin Proc, 2009; 84: 958-72.

5. Peetla C, Stine A, Labhasetwar V. Biophysical interactions with model lipid membranes: applications in drug discovery and drug delivery. Mol Pharmaceutics, 2009; 6: 1264-76.

6. Shrestha H, Bala R, Arora S. Lipid-based drug delivery systems. J Pharmaceutics, 2014; 801820: 1-10.

7. Turker S, Wassall S, Stillwell W, Severcan F. Convulsant agent pentylenetetrazol does not alter the structural and dynamical properties of dipalmitoylphosphatidylcholine model membranes. J Pharma Biomed Anal, 2011; 54: 379-386.
8. Ezer N, Sahin I, Kazanci N. Alliin interacts with DMPC model membranes to modify the membrane dynamics: FTIR and DSC Studies. Vib Spect, 2017; 89: 1-8.

9. Sahin I, Bilge D, Kazanci N, Severcan F. Concentration dependent effect of melatonin on DSPC membrane. J Mol Struc, 2013; 1052: 183-8.

10. Shrestha H, Bala R, Arora S. Lipid-based drug delivery systems. J Pharmaceu, 2014; 801820: 1-10.

11. Barroso R, Basso G, Costa-Filho A. Interactions of the antimalarial amodiaquine with lipid model membranes. Chem Phys Lipid, 2015; 186: 68-78.

12. Darwish $M$, Kirby $M$, Hellriegel ET, Robertson P. Armodafinil and modafinil have substantially different pharmacokinetic profiles despite having the same terminal half-lives: analysis of data from three randomized, single-dose, pharmacokinetic studies. Clin Drug Investig, 2009; 29: 613-23.

13. Nuvigil. North Wales, PA: Teva Pharmaceuticals USA, Inc.; 2013.

14. Boltz JR, Feigenson GW. A novel strategy for the preparation of liposomes: rapid solvent exchange. BBA, 1999; 1417: 232-45. 
15. Liossi A, Ntountaniootis D, Becker-Baldus J. Exploring the interactions of irbesartan and irbesartan-2-hydroxylpropyl-beta-cyclodextrin complex with model membranes. BBA-Biomemb, 2017; 1862: 1089-98.

16. Jagalski V, Barker R, Topgaard D, Cardenas M. Biophysical study of resin acid effects on phospholipid membrane structure and properties. BBA-Biomemb, 2016; 1858: 2827-38.

17. Augustynska D, Burda K, Jemiola-Rzeminska $M$. Temperature-dependent bifurcation of cooperative interactions in pure and enriched in beta-carotene DPPC liposomes. Chemico-Biol Int, 2016; 256: 23648.

18. Sekowski S, lonov $M$, Dubis A, Mavlyanov $S$, Bryszewska M. Biomolecular interactions of tannins isolated from Oenothera gigas with liposomes. J Memb Biol, 2016; 249: 171-9.

19. Altunuyar C, Sahin I, Kazanci N. A comparative study of the effects of cholesterol and desmosterol on DPPC model membranes. Chem Phys Lipid, 2015; 188: $37-45$.

20. Korkmaz F, Severcan F. Effect of progesterone on DPPC membrane: evidence for lateral phase separation and inverse action in lipid dynamics, Arch Biochem Biophys. 2005;440(2):141-7.

21. Türker-Kaya S, Kına A, Alın S. Divergent interaction profiles of gabapentin and levetiracetam with dipalmitoylphosphatidylcholine lipids, Int J Epi, 2017; 4: 150-8.

22. Engelke M, Jessel R, Wiechmann A, Diehl H. Effect of inhalation anesthetic on the phase behavior, permeability and order of phosphatidylcholine bilayers. Biophys Chem, 1997; 67: 127-38.

23. Brandenburg K, Seydel U. Investigation into the fluidity of lipopolysaccharide and free lipid A membrane systems by Fourier-transform infrared spectroscopy and differential scanning calorimetry. European J Biochem, 1990; 191: 229-36.
24. https://pubchem.ncbi.nlm.nih.gov/compound/ Armodafinil\#section=Top (accessed on 20.06.2017).

25. Nogueira AOD, de Sousa RS, Pereira LS, Mallmann C, Ferreira AD, Clementin RM, de Lima VR. Physicochemical interactions among alphaeleostearic acid-loaded liposomes applied to the development of drug delivery systems. J Mol Str, 2018;1154:248-255.

26. Silva LAD, Cintra ER, Alonso ECP, Alves GL, Lima EM, Taveira SF, da Cunha MSS, Marreto RN, Selection of excipients for the development of carvedilol loaded lipid-based drug delivery systems. J Therm Anal Cal, 2017; 130 :1593-1604.

27. Potamitis C, Chatzigeorgiou P, Siapi E, Viras K, Mavromoustakos T, Hodzic A, et al. Interactions of the AT1 antagonist valsartan with dipalmitoylphosphatidylcholine bilayers. BBA-Biomemb, 2011; 1808: $1753-63$.

28. Kato N, Ishijima A, Inaba T, Nomura F, Takeda S. Effects of lipid composition and solution conditions on the mechanical properties of membrane vesicles. Memb. (Basel), 2015; 5: 22-47.

29. Tresset G, The multiple faces of self-assembled lipidic systems, PMC Biophy, 2009; 2(3):1-6.

30. S. Tristram-Nagle. Use of X-ray and neutron scattering methods with volume measurements to determine lipid bilayer structure and number of water molecules/lipid. In E. A. Disalvo Ed. Membrane hydration: The role of water in the structure and function of biological membranes (Subcellular biochemistry) (Springer, 2015) pp 1743.

31. Heimburg T. A model for the lipid pretransition: coupling of ripple formation with the chain-melting transition. Biophys J, 2000; 78: 1154-65.

32. Lombardi D, Cuenoud B, Kramer SD. Lipid membrane interactions of indacaterol and salmeterol: do they influence their pharmacological properties? European J Pharmaceu Sci, 2009; 38: 533-47. 
33. Nicolle LE, Zhanel GG, Harding GK. Microbiological outcomes in women with diabetes and untreated asymptomatic bacteriuria. World J Urol, 2006; 24(1): 61-5.

34. Harding GK, Zhanel GG, Nicolle LE, Cheang M. Manitoba Diabetes Urinary Tract Infection Study Group. Antimicrobial treatment in diabetic women with asymptomatic bacteriuria. N Engl J Med, 2002; 347(20):1576-83.

35. Schwartz J, Thomas R, Drake C. Armodafinil in the treatment of sleep/wake disorders. Neuropsychiatric Dis Treat, 2010; 6: 417-27.
36. Yeagle PL. The structure of Biological Membrane, 3 rd. ed. New York: CRC Press; 2011.

37. Moore DJ, Sills RH, Mendelsohn R. Peroxidation of erythrocytes: FTIR spectroscopy studies of extracted lipids, isolated membranes, and intact cells. Biospectra J, 1995; 1: 133-40.

38. Turker S, Severcan M, Ilbay G, Severcan F. Epileptic seizures induce structural and functional alterations on brain tissue membranes. BBA-Biomemb, 2014; 1838: 3088-96. 